\title{
Improved Stability of the Palm Oil-in-Water Emulsion via the Surface Modification of Droplets with a Chitosan-Casein Complex Layer
}

\author{
Takashi KUROIWA ${ }^{1,2, \dagger}$, Yaeko OKUYAMA ${ }^{1}$, Akihiko KANAZAWA ${ }^{1}$ \\ ${ }^{1}$ Department of Applied Chemistry, Faculty of Science and Engineering, Tokyo City University, \\ 1-28-1 Tamazutsumi, Setagaya, Tokyo 158-8557, Japan \\ ${ }^{2}$ Advanced Research Laboratories, Tokyo City University, 8-15-1 Todoroki, Setagaya, Tokyo 158-0082, Japan
}

\begin{abstract}
The stabilization effect of a biopolymer complex layer consisting of sodium caseinate (SC) and chitosan $(\mathrm{CHI})$ formed via electrostatic interaction was investigated using an oil-in-water $(\mathrm{O} /$ W) emulsion containing palm oil droplets as the dispersed phase. $\mathrm{O} / \mathrm{W}$ emulsions containing palm oil droplets with a narrow droplet diameter distribution were successfully prepared using two microchannel emulsification devices using SC as an emulsifier at $60^{\circ} \mathrm{C}$. Surface modification of the palm oil droplets was conducted using different $\mathrm{CHI} / \mathrm{SC}$ ratios. The surface charge of the droplets was negative and positive at $\mathrm{CHI} / \mathrm{SC}$ ratios of less than 0.025 and more than 2.5 , respectively. At an intermediate $\mathrm{CHI} / \mathrm{SC}$ ratio between 0.025 and 2.5, the droplets formed large aggregates and became polydisperse. The adsorption of $\mathrm{CHI}$ on the surface of palm oil droplets at a high $\mathrm{CHI} / \mathrm{SC}$ ratio was confirmed by fluorescent microscopy and $\zeta$-potential measurement. Improved stability of the $\mathrm{O} /$ $\mathrm{W}$ emulsions with the $\mathrm{CHI}-\mathrm{SC}$ complex layer was demonstrated during heating $\left(60^{\circ} \mathrm{C}\right)$ and cooling $\left(20^{\circ} \mathrm{C}\right)$ treatment, and long-term $(7$ months $)$ storage at room temperature $\left(20-25^{\circ} \mathrm{C}\right)$. Interestingly, separation of the large oil phase on the top of the emulsion samples and the formation of large crystals of palm oil were suppressed in the emulsion samples with the CHI-SC complex layer.
\end{abstract}

Keywords: emulsion stability, solid/semi-solid lipid, microchannel emulsification, biopolymer complexation, electrostatic deposition

\section{Introduction}

Emulsions are defined as thermodynamically unstable dispersions consisting of two immiscible liquids, one of which is dispersed as small spherical droplets in the other [1,2], such as oil-in-water $(\mathrm{O} / \mathrm{W})$, water-in-oil $(\mathrm{W} / \mathrm{O})$, and water-in-oil-in-water $(\mathrm{W} / \mathrm{O} / \mathrm{W})$ emulsions. These emulsions are produced using not only liquid oils, but also solid/semi-solid fats that are solidified under their melting temperature as both dispersed and continuous oil phases (here, we use the term of "emulsion" as dispersions containing both liquid oil droplets and solidified or semi-solidified fat particles formed by cooling their melted droplets; we use the term of "droplet" regardless of whether it exists as liquid droplets or solid/semi-solid particles). Emulsions containing solid/ semi-solid fats show characteristic instabilities that are different from those containing liquid oils. The formation and melting of lipid crystals due to temperature changes significantly affect the colloidal interaction

(Received 25 Aug. 2021: accepted 20 Oct. 2021)

$\dagger$ Fax: +81-3-5707-1171, E-mail: tkuroiwa@tcu.ac.jp between oil droplets and fat particles. In the case of $\mathrm{O} /$ $\mathrm{W}$ emulsions, for example, partial coalescence between two or more droplets is induced by the formation and movement of lipid crystals at oil-water interfaces or deformation of droplets due to the polymorphic transition of lipid crystals [3-8]. The instability of $\mathrm{O} / \mathrm{W}$ emulsions containing solid/semi-solid fats is often problematic in their production, distribution, and storage processes [6-8].

In $\mathrm{O} / \mathrm{W}$ emulsions, crystallization of oil/fat droplets dispersed in an aqueous phase are affected by various additional factors, such as the type of oil phase, type of emulsifier, dispersed phase volume fraction, cooling rate, etc. [3-8]. The instability of $\mathrm{O} / \mathrm{W}$ emulsions due to crystallization of the oil phase involves interfacial phenomena between the oil and aqueous phases. Reportedly, the destabilization of $\mathrm{O} / \mathrm{W}$ emulsions along with crystallization is affected significantly by the type of nucleation at the interface covered with emulsifiers [5,8,9-11], the position and orientation of crystals [3,12,13], interfacial rheology $[1,3,14,15]$, and shear field around droplets [1, 2,16-17]. These factors affect emulsion stability during processing, distribution, and storage. In addition, con- 
trolling the physicochemical properties of emulsions has been attracting attention in "controlled release" technology for delivery systems of bioactive compounds, including controlling the gastrointestinal fate of emulsions $[2,7,18,19]$. Based on this background, it is desirable to establish methods for controlling the interfacial properties of $\mathrm{O} / \mathrm{W}$ emulsions containing solid/semi-solid oil phases.

Surface modification techniques have been developed as a methodology for preventing emulsion droplets from aggregation and coalescence, as well as controlling digestibility $[2,18,19,20]$. Among them, the deposition of edible biopolymers at the oil-water interface of emulsion droplets has been widely studied to stabilize $\mathrm{O} / \mathrm{W}$ emulsions [21-23]. Previously, the effects of various factors, such as the types of biopolymers used, addition conditions of biopolymers, and the interactions between biopolymers and emulsifiers, on the stability of the emulsion were evaluated by experimental and theoretical approaches [24-31]. Although this method has been applied to various $\mathrm{O} / \mathrm{W}$ and $\mathrm{W} / \mathrm{O} / \mathrm{W}$ emulsions, the effectiveness of this method has not been demonstrated for $\mathrm{O} / \mathrm{W}$ emulsions containing solid/semi-solid lipids as the dispersed oil phase. Therefore, it is important to clarify the effectiveness of surface modification of oil droplets containing solid/semi-solid lipids using the biopolymer deposition technique in order to understand the basic behavior of emulsified foods and develop advanced products with high quality and functionality.

In this study, we investigated the effect of surface modification of oil droplets in an $\mathrm{O} / \mathrm{W}$ emulsion containing a solid/semi-solid oil phase using a complex layer formed by two edible biopolymers. Here, we used palm oil as the oil phase material. Palm oil is a natural vegetable oil made from the fruits of the oil palm tree and mainly consists of palmitic, oleic, and linoleic acids [32, 33]. Palm oil has a melting point of $30-35^{\circ} \mathrm{C}$ [32]; thus, it exists as solid/semi-solid vegetable fat at room temperature and exhibits very complicated polymorphic crystallization behavior [34]. It is widely used in the food industry, such as cocoa butter equivalents and fly oil [35]. Therefore, we believe that the use of palm oil as a model lipid for evaluating the behavior of solid/semi-solid fat in $\mathrm{O} / \mathrm{W}$ emulsions has potential significance from a practical viewpoint.

To investigate the stability of the emulsions, we used a microchannel (MC) emulsification technique [36,37] to produce uniform palm oil droplets with a very narrow droplet size distribution [38]. The uniformity of droplet size in the evaluated emulsions is important for visualizing the changes in individual droplets and to avoid any uncertainties in the history of each droplet due to their polydispersity. The use of sodium caseinate (SC), which has a negative net charge at a $\mathrm{pH}$ higher than its isoelectric point (pI, approximately 4.5) [39-41], as an emulsifier enables the production of negatively charged monodisperse palm-oil droplets by $\mathrm{MC}$ emulsification. The positively charged polysaccharide, chitosan (CHI), is expected to interact with the negatively charged $\mathrm{SC}$ via electrostatic interaction, resulting in the formation of a CHI-SC complex layer at the oil-water interface of the palm oil droplets. A previous study using CHI as a biopolymer to form biopolymer deposited layers with negatively charged emulsifiers revealed that the formation of a biopolymer complex layer at the oil-water interface of $\mathrm{O} / \mathrm{W}$ emulsions affected the stability of oil droplets against aggregation and coalescence [27]. However, few studies have evaluated the effect of biopolymer complex layers on the stability of emulsions containing solid/ semi-solid lipids, such as palm oil. We believe that this study is the first to demonstrate the improved stability of the palm oil-containing $\mathrm{O} / \mathrm{W}$ emulsion with a biopolymer complex layer under heating-cooling experiments as well as its long-term stability during storage for 7 months at room temperature.

\section{Materials and methods}

\subsection{Materials}

Palm oil (refined, analytical grade) was purchased from Sigma-Aldrich (St. Louis, MO, USA). This palm oil mainly consisted of oleic acid (35-50\%), palmitic acid (35-50\%), linoleic acid (6-13\%), stearic acid (3-7\%), and myristic acid $(0.5-6 \%)$, as determined by the supplier. SC (12.6-15.8\% as nitrogen after drying), CHI ("Chitosan 10," degree of deacetylation: $84.6 \%$, mean molecular weight: 150,000 determined by the viscometric method [42]), sodium chloride $(\mathrm{NaCl})$, acetic acid, sodium hydroxide $(\mathrm{NaOH})$, and sodium azide were purchased from FUJIFILM Wako Pure Chemical Corporation (Osaka, Japan). Fluorescein isothiocyanate (FITC) isomer I was purchased from Sigma-Aldrich (St. Louis, MO, USA). The water used in all experiments was prepared using a Direct- $\mathrm{Q}$ water purification system (Merck Millipore Corporation, Billerica, USA) and had a resistivity of $18.2 \mathrm{M} \Omega \mathrm{cm}$. 


\subsection{MC emulsification for the preparation of monodisperse palm $\mathrm{O} / \mathrm{W}$ emulsion}

$\mathrm{O} / \mathrm{W}$ emulsions were prepared by $\mathrm{MC}$ emulsification using a laboratory-scale MC emulsification setup with grooved [43] or asymmetric straight-though [37] silicon MC plates (Fig. 1). The dimensions of the MCs [44, 45] fabricated on each silicon plate are shown in Fig. 1. The $\mathrm{MC}$ emulsification setup and silicon MC plates were purchased from EP-Tech (Hitachi, Japan).

Palm oil was preheated at $80^{\circ} \mathrm{C}$ for $1 \mathrm{~h}$ using a hot plate with magnetic stirring to liquefy it. The liquid oil was then loaded into a plastic syringe installed on a syringe pump (MSPE-1; AS ONE Corporation, Tokyo, Japan) and used as the to-be-dispersed phase. SC powder was added to $0.2 \mathrm{M} \mathrm{NaCl}$ solution at a concentration of $3 \mathrm{wt} \%$ and then stirred with a magnetic stirrer overnight. The prepared SC solution was loaded into a glass syringe installed on a syringe pump (SPE-1; AS ONE Corporation, Tokyo, Japan) and used as the continuous phase. The emulsification module with an installed silicon MC plate and glass plate was initially filled with a continuous phase. Both the to-be-dispersed and continuous phases were fed to the module using two syringe

\section{MC-A (Cross-flow type)}
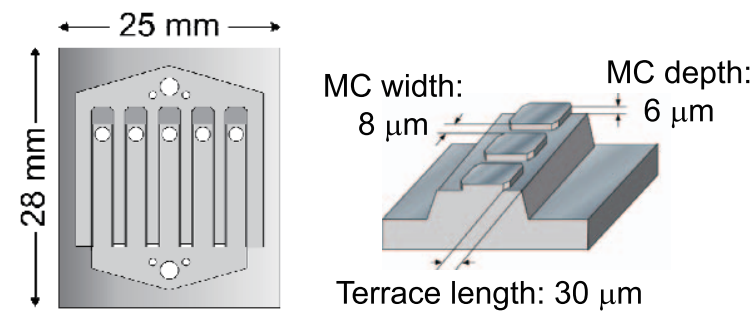

(1070 MCs/plate)

Terrace length: $30 \mu \mathrm{m}$

\section{MC-B (Straight-through type)}

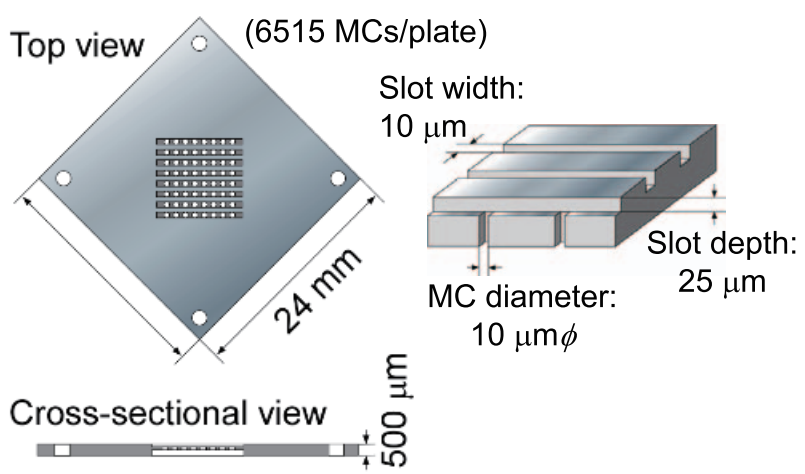

Fig. 1 Schematic illustration of the microchannel (MC) plates used in this study. Left and right pictures represent the shape of whole plates and enlarged illustration of MC-fabricated parts with their dimensions, respectively. pumps. The flow rates of the to-be-dispersed and continuous phases were set to 0.41 and $7.5 \mathrm{~mL} / \mathrm{h}$ for $\mathrm{MC}-\mathrm{A}$ or 1.3 and $150 \mathrm{~mL} / \mathrm{h}$ for $\mathrm{MC}-\mathrm{B}$, respectively. The plastic syringe containing palm oil and a plastic tube, by which the syringe and the module were connected, was heated to over $65^{\circ} \mathrm{C}$ using a ribbon heater to prevent the fed palm oil from solidifying during emulsification (typically for $1-2 \mathrm{~h}$ ). The temperature of the emulsification module was controlled using a water-circulating constant-temperature jacket and monitored using a digital thermometer (AD 5624; A\&D, Tokyo, Japan) during the emulsification experiments. The emulsification in the MC module was observed through a glass plate using a microscope video system equipped with a digital CCD camera $(\mathrm{QN}-$ C301; Qwonn Inc., Pottstown, PA, USA).

The droplet diameter distribution of the $\mathrm{O} / \mathrm{W}$ emulsion was measured using a laser diffraction particle size analyzer (SALD-200V ER; Shimadzu Corporation, Kyoto, Japan). The volume-weighed mean diameter $\left(d_{4,3}\right)$ and span factor $\left(\operatorname{span}=\left(d_{90}-d_{10}\right) / d_{50}\right.$, where $d_{\mathrm{i}}$ represents the particle diameter corresponding to the cumulative particle volume of i vol\%) were obtained using a data analysis software (Wing SALD II; Shimadzu Corporation, Kyoto, Japan). Optical photomicrographs of $\mathrm{O} / \mathrm{W}$ emulsions were obtained under bright-field and fluorescent modes using an inverted microscope (CKX41; Olympus Corporation, Tokyo, Japan) with a fluorescent light source unit (U-LH50HG; Olympus Corporation, Tokyo, Japan).

\subsection{Droplet modification via surface coating with chitosan-casein complex layers}

The obtained SC-stabilized O/W emulsion (50 mL) was centrifuged at ca. $1000 \mathrm{rpm}$ using a manual centrifuge (Model 1011; AS ONE Corporation, Tokyo, Japan), and then $40 \mathrm{~mL}$ of the continuous phase was removed from the emulsion. The residual emulsion was mixed with $40 \mathrm{~mL}$ of water to dilute the SC in the continuous phase. The same procedure was repeated for the SC-diluted emulsions. Subsequently, the SC concentration in the continuous phase was $0.12 \mathrm{wt} \%$. After dilution of SC, sodium azide was added to the $\mathrm{O} / \mathrm{W}$ emulsion, resulting in a final concentration of $0.02 \mathrm{wt} \%$ of sodium azide.

One gram of CHI powder was suspended in $100 \mathrm{~mL}$ of water and stirred with a magnetic stirrer, and then $10 \mathrm{~mL}$ of $1 \mathrm{M}$ acetic acid solution was added dropwise to the mixture to dissolve CHI. After adjusting the $\mathrm{pH}$ of the mixture to 5.7 using a $1 \mathrm{M} \mathrm{NaOH}$ solution, the mixture 
was made up to $200 \mathrm{~mL}$ with water to obtain a $5 \mathrm{~g} / \mathrm{L} \mathrm{CHI}$ solution. The resultant solution was filtered to remove the remaining solids from the solution before use. The concentration of $\mathrm{CHI}$ was adjusted by dilution with an acetate buffer (50 mM, pH 5.7), if necessary.

Ten milliliters of the SC-diluted emulsion was added dropwise to $6 \mathrm{~mL}$ of the $\mathrm{CHI}$ solution with magnetic stirring, and the mixture was stirred for $30 \mathrm{~min}$ at room temperature $\left(\sim 25^{\circ} \mathrm{C}\right)$. The obtained mixture was stored overnight at room temperature prior to analysis. For the fluorescent observation of the oil droplets, FITC-labeled CHI (FITC-CHI), which was prepared according to previous literature [46], was dissolved in an acetate buffer (50 mM, pH 5.7) and used instead of the CHI solution in the above procedure.

The $\zeta$-potential of the emulsion droplets was determined from the electrophoretic mobility measured by a $\zeta$-potential analyzer (Zetasizer Nano Z; Malvern Instruments Ltd., Worcestershire, UK). Electrophoretic mobility was measured using the laser Doppler technique, using the monomodal mode and the Smoluchowski approximation to convert electrophoretic mobility to the $\zeta$-potential.

\subsection{Stability evaluation}

Comparisons were made between the stability of the SC-stabilized emulsions, with and without the addition of CHI. The stability of the emulsions was evaluated based on changes in the morphology of the droplets after being subjected to various treatments.

\subsubsection{Effect of thermal treatment}

Emulsion samples were transferred into glass test tubes and placed in an aluminum block bath at $60^{\circ} \mathrm{C}$ for $30 \mathrm{~min}$. The sample temperature reached to $55^{\circ} \mathrm{C}$ in 5 min and $60^{\circ} \mathrm{C}$ in 9 min during the heating treatment. The emulsion samples were then immediately cooled in a water bath at $20^{\circ} \mathrm{C}$ for at least $30 \mathrm{~min}$, and stored prior to analysis. The sample temperature reached to $20^{\circ} \mathrm{C}$ in 3 min during the cooling treatment.

\subsubsection{Long-term stability at room temperature}

The emulsion samples were transferred to glass vials. The vials were left for 7 months at room temperature, ranging from $20-25^{\circ} \mathrm{C}$. The top surface of the emulsion sample was observed using a free-angle digital microscope system consisting of a zoom lens (TS-93005; Sugitoh Co., Ltd., Tokyo, Japan), a CCD camera (STCTC-202USB-AS; Omron Sentech Co., Ltd., Ebina, Japan), and an angle stand (SKS-AS200C; Saitoh
Kougaku Co., Ltd., Yokohama, Japan). To obtain a polarized photomicrograph, a polarized observation unit (MSC-RV; MeCan Imaging, Inc., Fujimino, Japan) was installed in the digital microscope system.

\section{Results and discussion}

\subsection{Preparation of $\mathrm{O} / \mathrm{W}$ emulsion using $\mathrm{MC}$ emulsification devices}

Figure 2 shows the diameter distribution and optical photomicrographs of $\mathrm{O} / \mathrm{W}$ emulsions containing palm oil as the dispersed oil phase prepared by $\mathrm{MC}$ emulsification with SC as an emulsifier. Here, we used two different MC plates: grooved cross-flow type (MC-A) and asymmetric straight-through hole type (MC-B). Monodisperse O/W emulsions with narrow diameter distributions with 26.0 and $33.5 \mu \mathrm{m}$ of mean diameters were obtained using $\mathrm{MC}-\mathrm{A}$ and $\mathrm{MC}-\mathrm{B}$, respectively. These emulsions were used as primary emulsions for the following experiments.
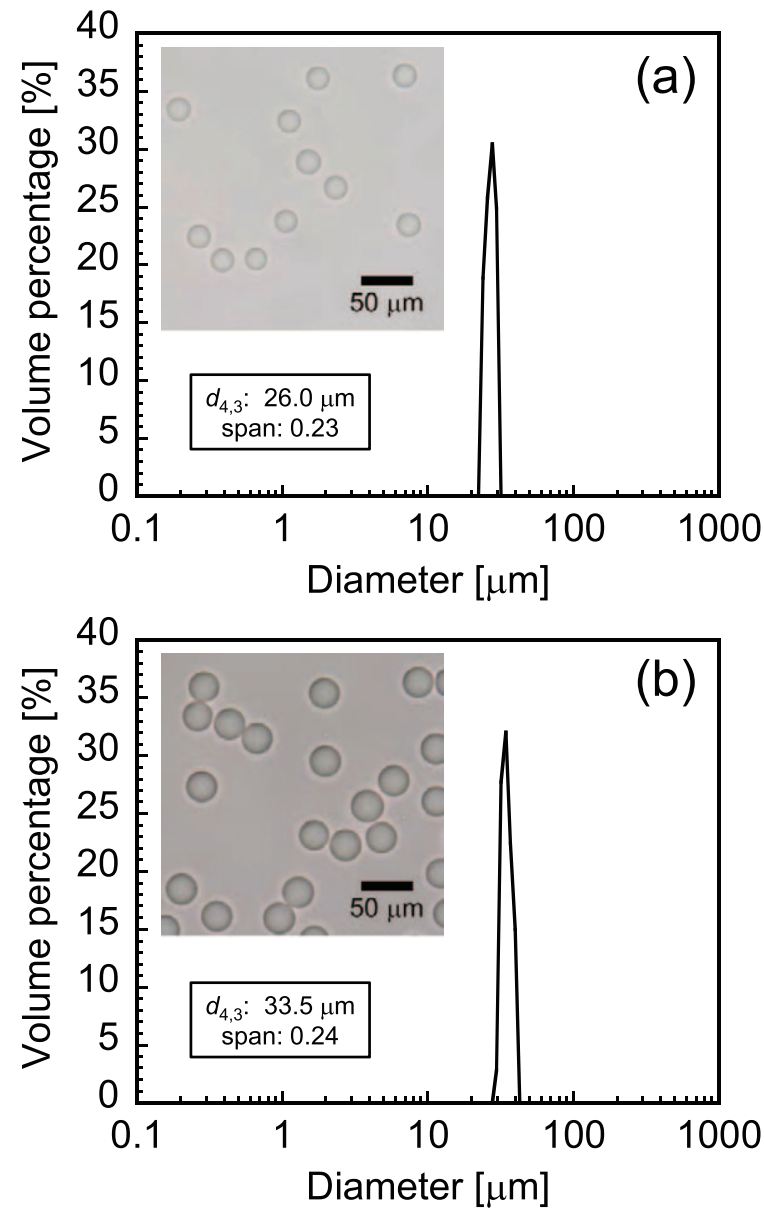

Fig. 2 Photomicrographs and diameter distributions of primary emulsions prepared by using the (a) grooved cross-flow type MC plate (MC-A) and (b) asymmetric straight-through hole type $\mathrm{MC}$ plate $(\mathrm{MC}-\mathrm{B})$. 


\subsection{Surface modification of oil droplets by electrostatic complexation of SC and CHI}

When the $\mathrm{pH}$ of the continuous phase was adjusted to 5.7 , SC would have a negative net charge because SC had a pI value of approximately 4.5. Therefore, palm oil droplets stabilized by an SC emulsifier were negatively charged in the continuous phase at that $\mathrm{pH}$. Based on this, we attempted to form a complex biopolymer layer by adding positively charged chitosan and evaluated its stabilizing effect on the oil droplets at room temperature.

Figure 3 shows the photomicrographs and droplet diameter distributions of $\mathrm{SC}$-stabilized $\mathrm{O} / \mathrm{W}$ emulsions mixed with $\mathrm{CHI}$ at different $\mathrm{CHI} / \mathrm{SC}$ ratios and then left at room temperature for $30 \mathrm{~min}$. Droplet morphology and dispersibility were maintained at low and high $\mathrm{CHI} / \mathrm{SC}$ ratios (0.0049 and 1.25; Fig. 3a and c), while severe flocculation upon the addition of $\mathrm{CHI}$ with a middle $\mathrm{CHI} / \mathrm{SC}$ ratio (0.078) was visually observed and detected by a large increase in particle size, as shown in both the photomicrograph and particle diameter distribution (Fig. 3b). Remarkably large droplets formed by coalescence were involved in the flocculated particles shown in Fig. 3, and they were aggregated with each other through bridging flocculation with aggregated polymers, caused by charge neutralization of $\mathrm{CHI}$ and $\mathrm{SC}$. This result agrees with the reported behaviors of the microstructure (a)

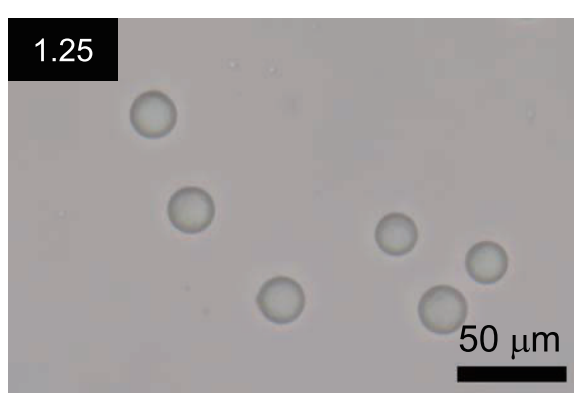

(b)

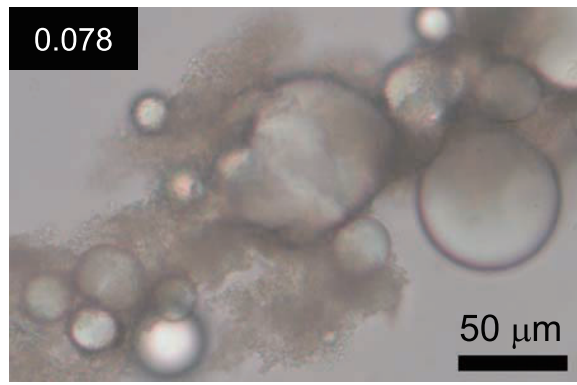

(c)

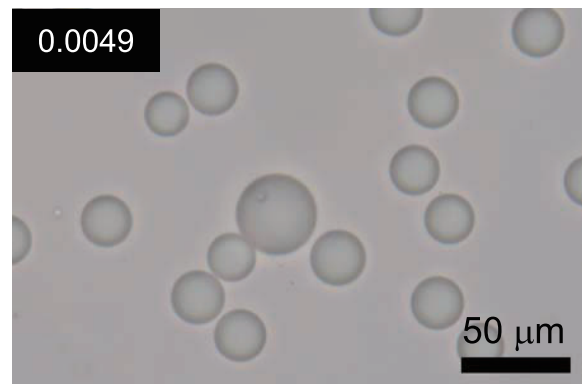

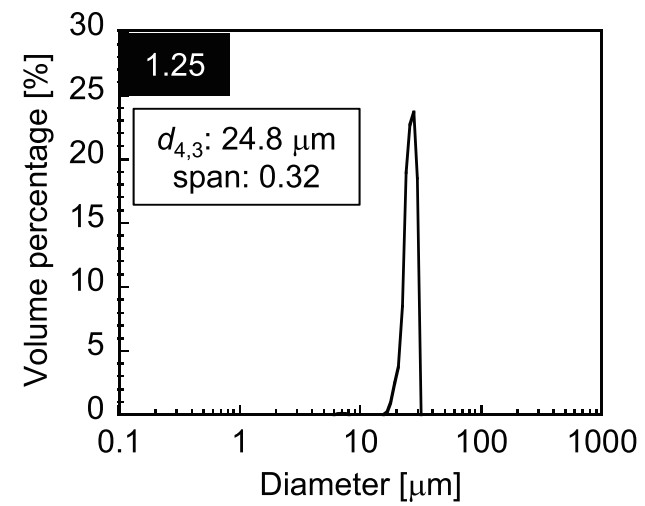
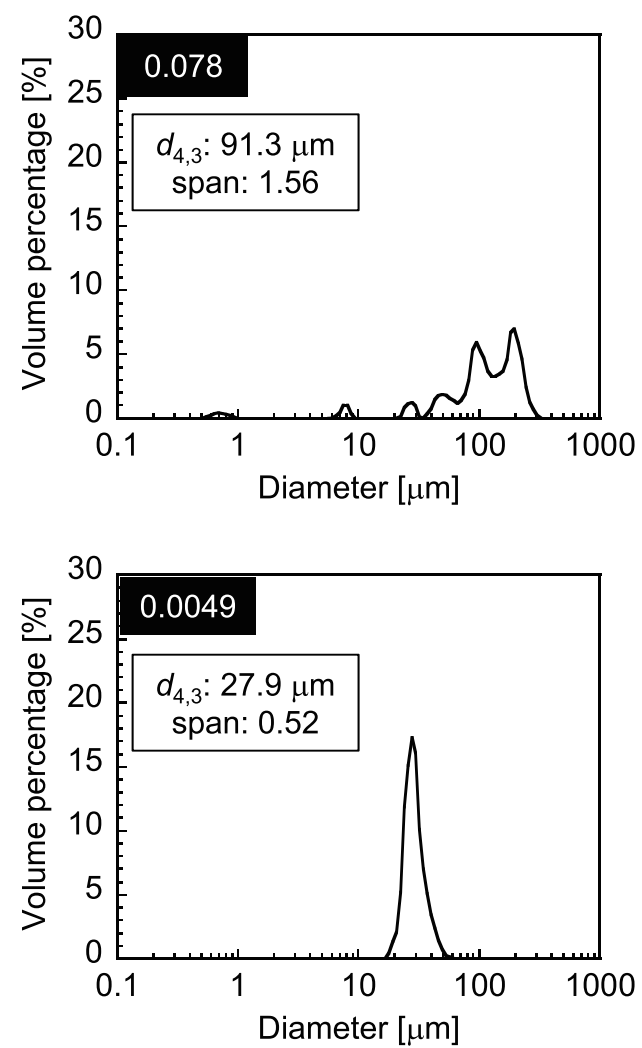

Fig. 3 Effect of chitosan (CHI)/sodium caseinate (SC) ratio on the particle morphology (left photomicrographs) and particle size distribution (right graphs) of the palm oil in water $(\mathrm{O} / \mathrm{W})$ emulsion. Values at upper-left corners of each panel indicate the CHI/SC ratio: (a) 1.25; (b) 0.078 ; (c) 0.0049 . Mean particle diameters $\left(d_{4,3}\right)$ and span values obtained by data analysis are also presented in the box in the graphs. 
of the emulsion droplets as well as its properties in other colloidal systems involving electrostatic interactions between biopolymers [27, 29].

Figure 4 shows the mean diameter, span, and $\zeta$-potential of the SC-stabilized palm oil droplets as a function of the $\mathrm{CHI} / \mathrm{SC}$ ratio. In the absence of $\mathrm{CHI}, d_{4,3}$, span, and the $\zeta$-potential on the surface of the SC-stabilized droplets were $26.0 \mu \mathrm{m}, 0.23$ (see Fig. 3a), and $-28.4 \mathrm{mV}$ respectively. A negative value of the $\zeta$-potential confirmed the presence of negatively charged SC at $\mathrm{pH} 5.0$. Stable emulsions were obtained at a $\mathrm{CHI} / \mathrm{SC}$ ratio of 0.01 and below, indicating that droplets could be dispersed by electrostatic repulsion between negatively charged droplet surfaces. As the CHI/SC ratio increased, the mean diameter and span value also increased because the droplets formed large aggregates (Fig. 4b). For CHI/SC ratio between 0.02 and 0.25 , we were unable to obtain reliable $\zeta$-potential measurements because of heavily

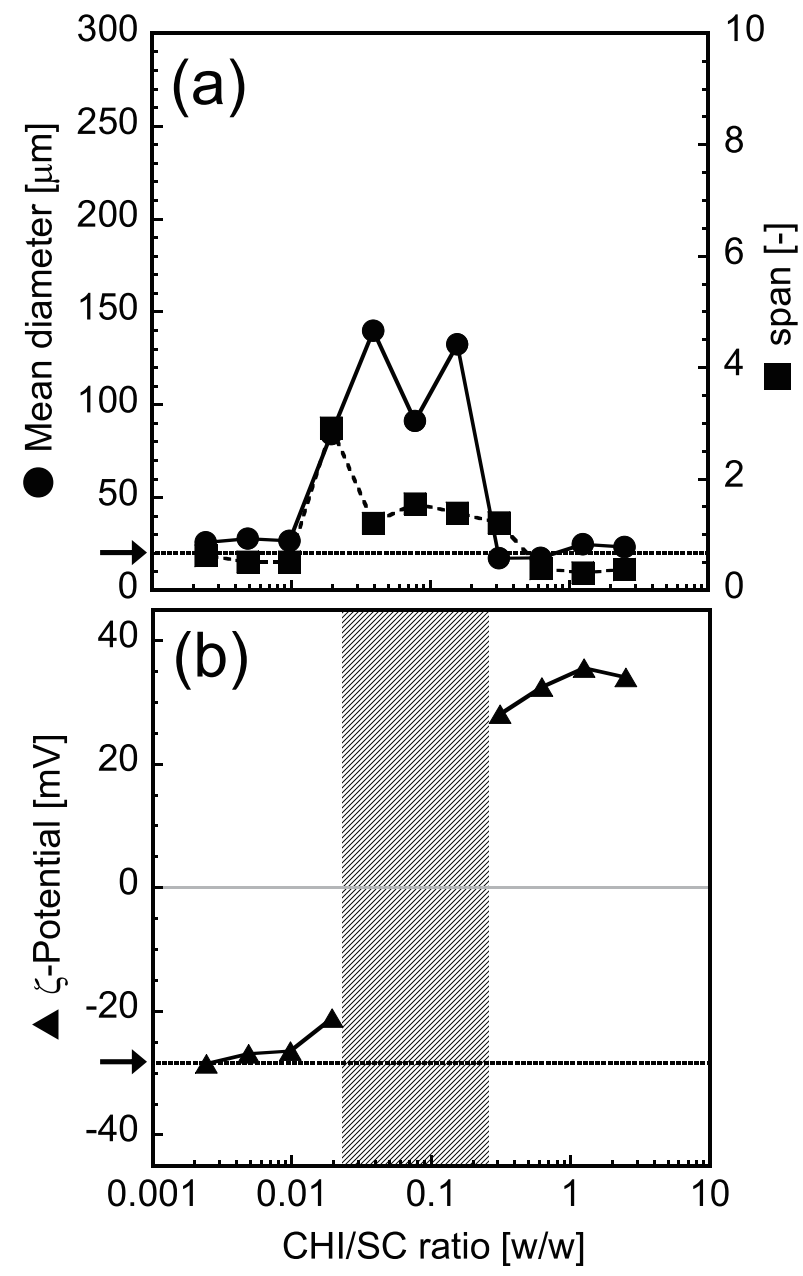

Fig. 4 Effect of CHI/SC ratio used for surface modification on the (a) diameter distribution and (b) $\zeta$-potential of palm oil droplets. The dotted lines with arrows indicate the values of mean diameter and $\zeta$-potential of SC-stabilized droplets without chitosan. aggregated particles formed via charge neutralization of $\mathrm{CHI}$ and SC. At CHI/SC ratios higher than 0.25, welldispersed droplets were obtained. These droplets had positive $\zeta$-potential values $(>+30 \mathrm{mV})$, indicating the formation of a cationic CHI layer adsorbed on the droplet surface.

To confirm the adsorption of chitosan onto the droplet surface, fluorescent microscopic observation of emulsion droplets was conducted using CHI labeled with FITC as a fluorescent marker. Fig. 5a shows a fluorescence image of palm oil droplets stabilized by the CHI-SC complex layer $(\mathrm{CHI} / \mathrm{SC}$ ratio $=2.5)$. The green fluorescence from FITC could be seen as a smooth thin ring surrounding the surface of the droplet, thus confirming the successful deposition of $\mathrm{CHI}$ forming complexes with SC via electrostatic interactions. The fluorescence intensity profile (Fig. 5b) was obtained by image analysis along the horizontal dotted line in Fig. 5a. Strong fluorescence was

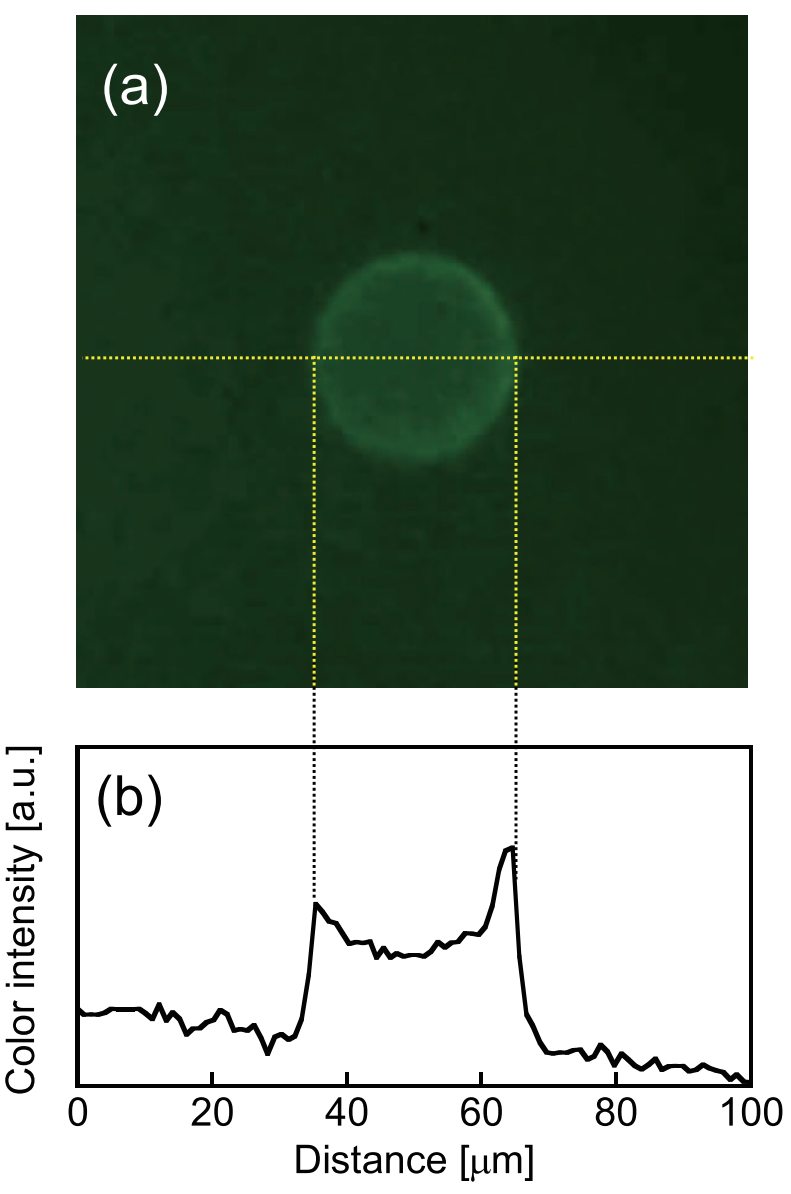

Fig. 5 (a) Fluorescence photomicrograph of a palm oil droplet stabilized by the CHI-SC complex layer. $\mathrm{CHI}$ was labeled with fluorescein isothiocyanate (FITC) for visualizing the adsorbed CHI. (b) Fluorescence intensity profile along the horizontal dotted line in (a). Green color intensity was quantified using an image analysis software, "ImageJ" (Java 1.6.0_24 64-bit) [i]. 
detected at the edge of the droplet; therefore, this fluorescence profile clearly indicated the localization of FITC-CHI on the surface of the droplet. Furthermore, after washing the external aqueous solution, fluorescence from FITC-CHI remained around the droplets, confirming the stable adsorption of $\mathrm{CHI}$ on the surface of the droplets. These results further support a $\zeta$-potential reversal from a negative value before $\mathrm{CHI}$ deposition to a positive value after adsorption of $\mathrm{CHI}$ forming complex with SC (Fig. 4b).

\subsection{Effect of CHI-SC complex layer on the stability of palm $\mathrm{O} / \mathrm{W}$ emulsion}

\subsubsection{Stability against heating and cooling treatment}

Next, we investigated the stability of palm oil droplets covered with and without a CHI-SC complex layer during the heating and cooling treatments. The $\mathrm{O} / \mathrm{W}$ emulsions were heated at $60^{\circ} \mathrm{C}$ for $30 \mathrm{~min}$ and then cooled at $20^{\circ} \mathrm{C}$ for $30 \mathrm{~min}$. These conditions correspond to those during emulsification at high temperatures and during storage at approximately room temperature. Reportedly, the crystalline structure of the palm oil used in this study disappeared at $57.5^{\circ} \mathrm{C}$ during the heating process, while the crystalline structure appeared below $27.5^{\circ} \mathrm{C}$ during the cooling process [38].

Figure 6 shows the effect of the CHI-SC complex layer on the morphology of palm oil droplets in $\mathrm{O} / \mathrm{W}$ emulsions after the heating-cooling treatment. Large oil droplets of several micrometers in size appeared on the top of the emulsion sample without the addition of CHI (Fig. 6a). In contrast, large droplet formation was not remarkable on the top of the emulsion sample stabilized by the $\mathrm{CHI}-\mathrm{SC}$ complex layer at a $\mathrm{CHI} / \mathrm{SC}$ ratio of 2.5 (Fig. 6b).
The palm oil droplets maintained their original diameter (ca. $30 \mu \mathrm{m}$ ) even after $24-\mathrm{h}$ of storage following the heating-cooling treatment, as confirmed by the photomicrograph of the top of the emulsion sample at higher magnification (Fig. 6c). These results suggest that the formation of a CHI-SC complex layer on the surface of palm oil droplets suppressed the coalescence of droplets induced during the heating-cooling treatment.

When two oil droplets are close to each other, there are attractive or repulsive forces between the droplets. In casein-stabilized $\mathrm{O} / \mathrm{W}$ emulsions, flocculation and coalescence of droplets are induced by the balance of these forces: an attractive force involving the bridging by a single casein molecule and repulsive forces are derived from steric and electrostatic interactions between adsorbed casein molecules [26, 47]. At a relatively high salt concentration $(>0.1 \mathrm{M})$ of the continuous aqueous phase in an emulsion, the attraction by the bridging presumably becomes of sufficient importance to form droplet aggregations, resulting in droplet coalescence or partial coalescence [47]. In aggregated or partially coalesced droplets, low-melting point triglycerides would flow on the surface of the aggregates near the oilwater interface when the temperature is raised to their melting points, which induces separation of the oil phase on the surface of the emulsion samples [4]. In addition, the instability of emulsion droplets/lipid microspheres has been reported to be strongly dependent on the orientation of lipid molecules at the oil-water interfaces based on their mobility near the interface $[3,5]$. When the CHI-SC complex layer was formed on the oil-water interface by adding an appropriate amount of $\mathrm{CHI}$, bridging between two or more droplets would be suppressed, as well as flocculation and coalescence of droplets, proba-
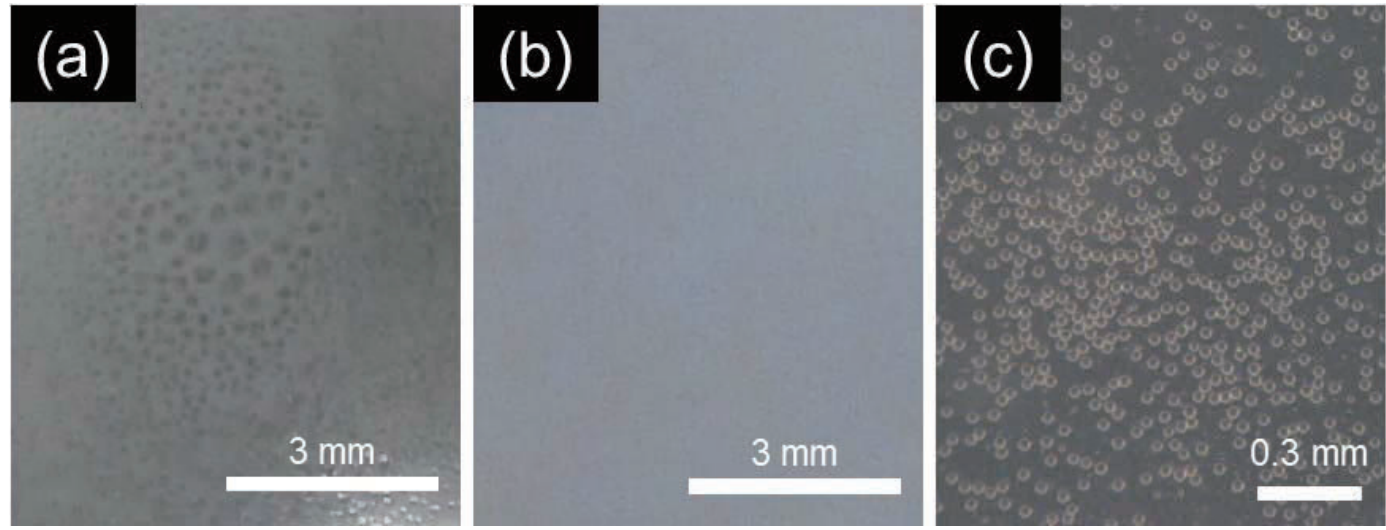

Fig. 6 Top views of the emulsion samples (a) without and (b) with CHI-SC complex layer after heating $\left(60^{\circ} \mathrm{C}\right.$, $30 \mathrm{~min}$ ), followed by cooling $\left(20^{\circ} \mathrm{C}, 30 \mathrm{~min}\right)$ treatment. (c) Photomicrograph of the same emulsion sample as (b) taken with a digital microscope. 
bly due to (1) formation of a physical barrier preventing droplets from the bridging, (2) enhancement of electrostatic and steric repulsion by the externally adsorbed $\mathrm{CHI}$ layer with a positive charge, and (3) suppression of oil movement at the oil-water interface by the CHI-SC complex layer with low molecular mobility.

\subsubsection{Long-term storage under room temperature}

Palm oil-containing $\mathrm{O} / \mathrm{W}$ emulsions with and without the CHI-SC complex layer were stored at room temperature $\left(20-25^{\circ} \mathrm{C}\right)$ for 7 months. Bright-field and polarized photomicrographs of both samples observed using a digital microscope are shown in Fig. 7. In the emulsion sample stabilized by only SC (Fig. 7a), polydisperse droplets over $100 \mu \mathrm{m}$ were observed with very large aggregates with needle-like morphology. Very few droplets with an initial droplet diameter $(\sim 30 \mu \mathrm{m})$ were observed at this time. Under polarized observation with crossed polarizing filters, these large aggregates show a birefringent texture (Fig. 7a, bottom picture), indicating the formation of needle-like crystals connecting each other. However, spherical droplets in the same sample did not show any birefringence, suggesting that the droplets were in an isotropic liquid state. This result indicates that the palm oil components with higher and lower melting points would be separated from each other as crystalline solids and liquid droplets, respectively, during long-term storage. In contrast, in the case of the emulsion sample stabilized by the CHI-SC complex layer, palm oil droplets keeping their starting diameter were observed even after storage at room temperature for 7 months. Interestingly, under polarized microscopic observation, birefringence derived from solidified palm oil was not found remarkably compared to the sample without the CHI-SC complex layer. This result suggests that the formation of the CHI-SC complex layer could suppress both the separation and crystallization of palm oil components during long-term storage at room temperature. Complexation of $\mathrm{CHI}$ and $\mathrm{SC}$ at the oil-water interface of palm oil droplets might reduce the mobility of SC molecules as well as palm oil components near the oil-water interface by multipoint electrostatic interactions between $\mathrm{CHI}$ and SC. This complex layer acts as a physical barrier against the mass transfer of oil components across the oil-water interface; thus, the separation of the palm oil component with lower melting points was suppressed during long-term storage. Furthermore, the CHI-SC complex layer prevents the droplets from being very close to each other due to electrostatic and steric repulsion at the oil-water interface. Although the detailed mechanisms of the suppression effect of the CHI-SC complex layer on the crystallization of palm oil droplets (a)

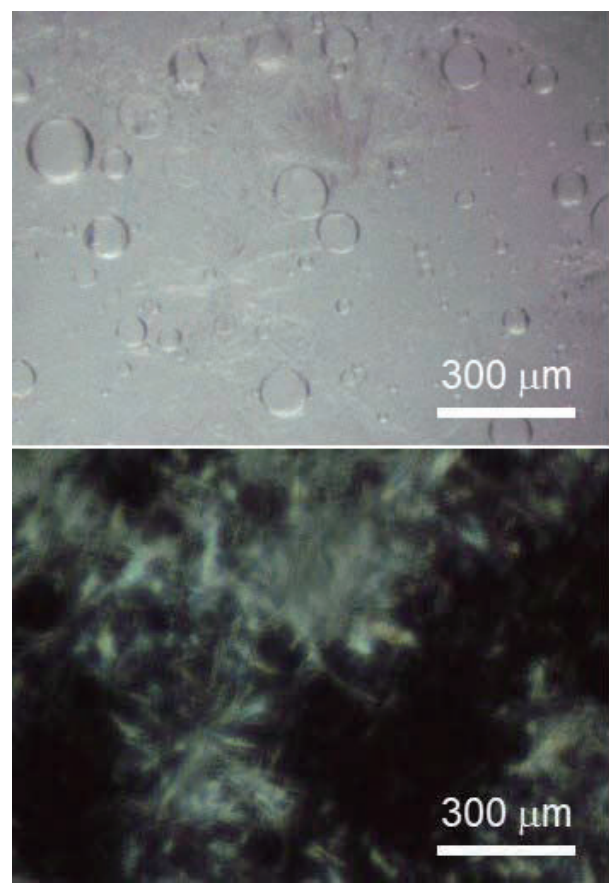

(b)

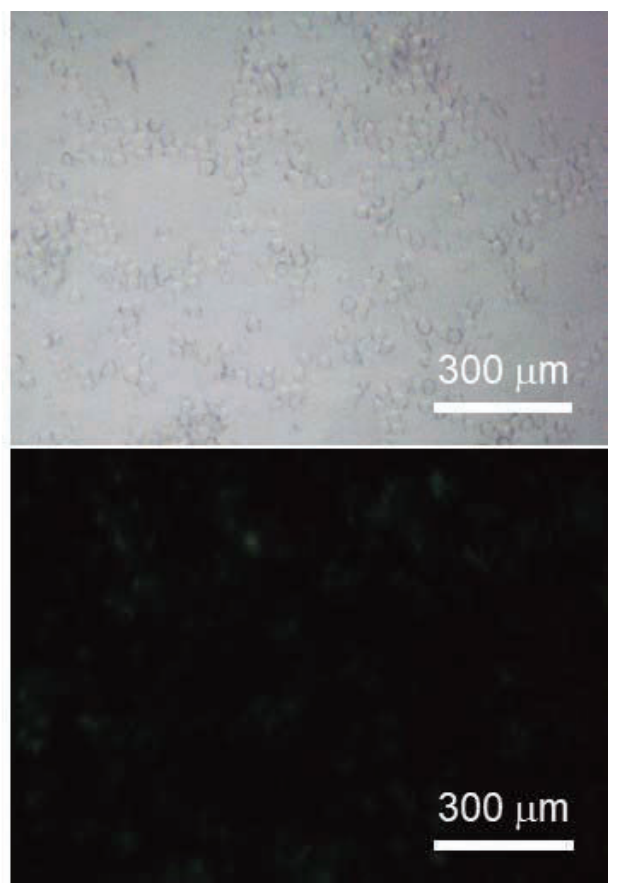

Fig. 7 Photomicrographs of the emulsion samples (a) without and (b) with CHI-SC complex layer after 7 -month storage at room temperature $\left(20-25^{\circ} \mathrm{C}\right)$. Top and bottom pictures were taken without and with crossed-polarizing filters, respectively. 
have not yet been clarified, we believe that the above results can contribute to improving the stability of emulsion foods and controlling their physicochemical behaviors during digestion.

\section{Conclusions}

The effect of the CHI-SC complex layer on the stability of oil droplets consisting of solid/semi-solid fats was investigated using $\mathrm{O} / \mathrm{W}$ emulsions containing monodisperse palm oil droplets prepared by $\mathrm{MC}$ emulsification. In the case of the $\mathrm{O} / \mathrm{W}$ emulsion with the $\mathrm{CHI}-\mathrm{SC}$ complex layer at the oil-water interface formed under appropriate conditions, the following stabilizing effects were demonstrated compared to those without the CHI-SC complex layer: (1) suppression effect on droplet coalescence and the resulting separation of the oil phase during heating-cooling treatment across the melting and solidifying temperatures; (2) suppression effect on droplet coalescence and formation of large lipid crystals during long-term storage for 7 months at room temperature. These effects might be derived from two possible factors: (1) the formation of a physical barrier between the oil droplets due to strong repulsive interactions and (2) less mass transfer through the oil-water interface due to the reduced mobility of palm oil components by complexation of $\mathrm{CHI}$ and $\mathrm{SC}$ at the oil-water interface. The mechanistic background of these results, however, has not yet been clarified. In practical applications of emulsion products consisting of solid/semi-solid lipids, the solidification and/or separation of lipid components often becomes a severe problem for quality control during their manufacture, distribution, and storage as well as their digestion behavior in the human body. We believe that further investigation in future studies may help to elucidate the potential usefulness of these edible biopolymer complexation techniques in improving the quality and functionality of lipid products.

\section{Acknowledgements}

This study was partly supported by the Japan Society for the Promotion of Science (JSPS) KAKENHI (No. 17K07824).

\section{NOMENCLATURE}

$d_{4,3}$ : volume-weighed mean diameter, $\mu \mathrm{m}$ span: span factor $\left(=\left(d_{90}-d_{10}\right) / d_{50}\right.$, where $d_{\mathrm{i}}$ represents the particle diameter corresponding to the cumulative particle volume of i vol\%)

\section{References}

1) E. Dickinson; "Introduction to Food Colloids", Oxford University Press, 1992.

2) D. J. McClements; "Food Emulsions (3rd Edition)", CRC Press, 2016.

3) D. Rousseau; Fat crystals and emulsion stability - a review. Food Res. Int., 33, 3-14 (2000).

4) S. A. Vanapalli, J. Palanuwech, J. N. Coupland; Stability of emulsions to dispersed phase crystallization: effect of oil type, dispersed phase volume fraction, and cooling rate. Coll. Surf. A: Physicochem. Eng. Aspects, 204, 227-237 (2002).

5) S. Arima, T. Ueji, S. Ueno, A. Ogawa, K. Sato; Retardation of crystallization-induced destabilization of PMF-in-water emulsion with emulsifier additives. Coll. Surf. B: Biointerf., 55, 98-106 (2007).

6) K. Sato, S. Ueno; Crystallization, transformation and microstructures of polymorphic fats in colloidal dispersion states. Curr. Opin. Coll. Interf. Sci., 16, 384-390 (2011).

7) D. J. McClements; Crystals crystallization in oil-in-water emulsions: Implications for emulsion-based delivery systems. Adv. Coll. Interf. Sci., 174, 1-30 (2012).

8) S. Arima; Fat crystals and physical properties of emulsion (in Japanese). Oleoscience, 16, 11-19 (2016).

9) J. N. Coupland; Crystallization in emulsions. Curr. Opin. Coll. Interf. Sci., 7, 445-450 (2002)

10) S. Ueno, Y. Hamada, K. Sato; Controlling polymorphic crystallization of n-alkane crystals in emulsion droplets through interfacial heterogeneous nucleation. Cryst. Growth Design, 3, 935-939 (2003).

11) M. Sakamoto, A. Ohba, J. Kuriyama, K. Maruo, S. Ueno, K. Sato; Influences of fatty acid moiety and esterification of polyglycerol fatty acid esters on the crystallization of palm mid fraction in oil-in-water emulsion. Coll. Surf. B: Biointerf., 37, 27-33 (2004).

12) Y. Shinohara, T. Takamizawa, S. Ueno, K. Sato, I. Kobayashi, M. Nakajima, Y. Amemiya; Microbeam X-ray diffraction analysis of interfacial heterogeneous nucleation of $n$-hexadecane inside oil-in-water emulsion droplets. Cryst. Growth Design, 8, 3123-3126 (2008)

13) S. Arima, S. Ueno, A. Ogawa, K. Sato; Scanning microbeam small-angle X-ray diffraction study of interfacial heterogeneous crystallization of fat crystals in oil-in-water emulsion droplets. Langmuir, 25, 9777-9784 (2009).

14) P. Fischer, P. Erni; Emulsion drops in external flow fields - 
the role of liquid interfaces. Curr. Opin. Coll. Interf. Sci., 12, 196-205 (2007).

15) S. Narayan, A .E Metaxas, R. Bachnak, T. Neumiller, C. S. Dutcher; Zooming in on the role of surfactants in droplet coalescence at the macroscale and microscale. Curr. Opin. Coll. Interf. Sci., 50, 101385 (2020).

16) G. T. Fuller, T. Considine, M. Golding, L. Matia-Merino, A. MacGibbon, G. Gillies; Aggregation behavior of partially crystalline oil-in-water emulsions: Part I Characterization under steady shear. Food Hydrocolloids, 43, 521-528 (2015).

17) G. T. Fuller, T. Considine, M. Golding, L. Matia-Merino, A. MacGibbon; Aggregation behavior of partially crystalline oil-in-water emulsions: Part II — Effect of solid fat content and interfacial film composition on quiescent and shear stability. Food Hydrocolloids, 51, 23-32 (2015).

18) D. J. McClements, E. A. Decker, J. Weiss, Emulsion-based delivery systems for lipophilic bioactive components. J. Food Sci., 72, 109-124 (2007).

19) D. J. McClements; "Nanoparticle- and Microparticle-Based Delivery Systems”, CRC Press, 2015.

20) E. Dickinson; Interfacial structure and stability of food emulsions as affected by protein-polysaccharide interactions. Soft Matter, 4, 932-942 (2008).

21) D. Guzzey, D. J. McClements; Formation, stability and properties of multilayer emulsions for application in the food industry. Adv. Coll. Interf. Sci., 128-130, 227-248 (2006).

22) B. Zeeb, C. Thongkaew, J. Weiss; Theoretical and practical considerations in electrostatic depositioning of charged polymers. J. Appl. Polym. Sci., 131, 40099 (2014).

23) T. Kuroiwa, I. Kobayashi, A. M. Chuah, M. Nakajima, S. Ichikawa; Formulation and stabilization of nano-/microdispersion systems using naturally occurring edible polyelectrolytes by electrostatic deposition and complexation. Adv. Coll. Interf. Sci., 226, 86-100 (2015).

24) S. Ogawa, E. A. Decker, D. J. McClements; Influence of environmental conditions on the stability of oil in water emulsions containing droplets stabilized by lecithin-chitosan membranes. J. Agric. Food Chem., 51, 5522-5527 (2003).

25) S. Ogawa, E. A. Decker, D. J. McClements; Production and characterization of $\mathrm{O} / \mathrm{W}$ emulsions containing droplets stabilized by lecithin-chitosan-pectin multilayered membranes. J. Agric. Food Chem., 52, 3595-3600 (2004).

26) D. J. McClements; Theoretical analysis of factors affecting the formation and stability of multilayered colloidal dispersions. Langmuir, 21, 9777-9785 (2005).

27) A. M. Chuah, T. Kuroiwa, I. Kobayashi, M. Nakajima; Effect of chitosan on the stability and properties of modified lecithin stabilized oil-in-water monodisperse emulsion pre- pared by microchannel emulsification. Food Hydrocolloids, 23, 600-610 (2009).

28) G. T. Vladisavljević, D. J. McClements; Modification of interfacial characteristics of monodisperse droplets produced using membrane emulsification by surfactant displacement and/or polyelectrolyte electrostatic deposition. Coll. Surf. A: Physicochem. Eng. Aspects, 364, 123-131 (2010).

29) A. M. Chuah, T. Kuroiwa, I. Kobayashi, M. Nakajima; The infuluence of polysaccharide on the stability of protein stabilized oil-in-water emulsion prepared by microchannel emulsification technique. Coll. Surf. A: Physicochem. Eng. Aspects, 440, 136-144 (2014).

30) N. Iwata, M. A. Neves, J. Watanabe, S. Sato, S. Ichikawa; Stability control of large oil droplets by layer-by-layer deposition using polyelectrolyte dietary fibers. Coll. Surf. A Physicochem. Eng. Aspects, 440, 2-9 (2014).

31) Y. Yamanaka, I. Kobayashi, M. A. Neves, S. Ichikawa, K. Uemura, M. Nakajima; Formulation of W/O/W emulsions loaded with short-chain fatty acid and their stability improvement by layer-by-layer deposition using dietary fibers. LWT-Food Sci. Technol., 76B, 344-350 (2017).

32) D. O. Edem; Palm oil: Biochemical, physiological, nutritional, hematological, and toxicological aspects: a review. Plant Foods Hum. Nutr., 57, 319-341 (2002).

33) R. Sambanthamurthi, K. Sundram, Y. A. Tan; Chemistry and biochemistry of palm oil. Prog. Lipid Res., 39, 507-558 (2000).

34) L. C. Chong, Z. Kamarudin, P. Lesieur, A. Marangoni, C. Bourgaux, M. Ollivon; Thermal and structural behaviour of crude palm oil: crystallisation at very slow cooling rate. Eur. J. Lipid Sci. Technol., 109,410-421 (2007).

35) O. I. Mba, J. Dumont, M. Ngadi; Palm oil: Processing, characterization, and utilization in the food industry - A review. Food Biosci., 10, 2-41 (2015).

36) T. Kawakatsu, Y. Kikuchi, M. Nakajima; Regular-sized cell creation in microchannel emulsification by visual microprocessing method. J. Am. Oil Chem. Soc., 74,317-321 (1997).

37) I. Kobayashi, S. Mukataka, M. Nakajima; Novel asymmetric through-hole array microfabricated on a silicon plate for formulating monodisperse emulsions. Langmuir, 21, 76297632 (2005).

38) T. Kuroiwa, M. Ito, Y. Okuyama, K. Yamashita, A. Kanazawa Protein-stabilized palm-oil-in-water emulsification using microchannel array devices under controlled temperature. Molecules, 25, 4805 (2020).

39) E. D. Strange, V. H. Holsinger, D. H. Kleyn; Chemical properties of thiolated and succinylated caseins. J. Agric. Food Chem., 41, 30-36 (1993).

40) K. E. Allen, E. Dickinson, B. Murray; Acidified sodium 
caseinate emulsion foams containing liquid fat: a comparison with whipped cream. LWT, 39, 225-234 (2006).

41) H. Ma, P. Forssell, R. Partanen, R. Seppänen, J. Buchert, H. Boer; Sodium caseinates with an altered isoelectric point as emulsifiers in oil/water systems. J. Agric. Food Chem., 57, 3800-3807 (2009).

42) W. Wang, S. Bo, S. Li, W. Qin; Determination of the MarkHouwink equation for chitosans with different degrees of deacetylation. Int. J. Biol. Macromol., 13, 281-285 (1991).

43) A. M. Chuah, T. Kuroiwa, I. Kobayashi, X. Zhang, M. Nakajima; Preparation of uniformly sized alginate microspheres using the novel combined methods of microchannel emulsification and external gelation. Coll. Surf. A: Physicochem. Eng. Aspects, 351, 9-17 (2009).

44) S. Sugiura, M. Nakajima, M. Seki; Effect of channel struc- ture on microchannel emulsification. Langmuir, 18, 57085712 (2002).

45) I. Kobayashi, Y. Hori, K. Uemura, M. Nakajima; Production Characteristics of large soybean oil droplets by microchannel emulsification using asymmetric through holes. Jpn. J. Food Eng., 11, 37-48 (2010).

46) M. Huang, Z. Ma, E. Khor, L. Y. Lim; Uptake of FITCchitosan nanoparticles by A549 cells. Pharm. Res., 19, 1488-1494 (2002).

47) E. Dickinson; Caseins in emulsions: interfacial properties and interactions. Int. Dairy J., 9, 305-312 (1999).

\section{URLs cited}

i) https://imagej.nih.gov/ij/ (Aug. 14, 2021). 


\title{
和文要約
}

\section{キトサンーカゼイン複合層を利用した液滴表面修飾による パーム油滴含有 $\mathrm{O} / \mathrm{W}$ エマルションの安定性向上}

\author{
黑岩 $\quad$ 崇 ${ }^{1,2, \dagger}$, 奥山椰英子 ${ }^{1}$, 金澤昭彦 ${ }^{1}$ \\ 1 東京都市大学理工学部応用化学科, ${ }^{2}$ 東京都市大学総合研究所
}

カゼインナトリウムを乳化剂としてマイクロチャネ ル乳化法で調製したパーム油含有 OWエマルションを 用いて, 半固体油脂からなる油滴の安定性に対するキ トサンーカゼイン複合層の効果について検討した，パー ム油の融解温度以上である $60^{\circ} \mathrm{C} に$ 打いてクロスフロー 型および貫通型マイクロチャネルアレイデバイスを用 い，平均液滴径がそ机ぞれ 26.0 および $33.5 \mu \mathrm{m}$ の単分 散エマルションを得た. CHI/SC比を種々変えて油滴 表層に CHI-SC 複合層の形成を試みたところ, CHI/SC 比が 0.025 以下打よび 2.5 以上ではそれぞれ負打よび正 のゼータ電位をもつ単分散油滴が得られた。これらの 中間の CHI/SC 比では, 油滴間の激しい凝集がみられ, エマルションは多分散化した。 ゼータ電位が正の值を 示す条件では, 油滴表層への CHI の吸着が確認され, カチオン性の CHI と正味電荷が負となる SC の複合層 の形成が示された. 加熱 - 冷却処理および長期保存に おける CHI-SC 複合層の添加効果を調べたところ，油 水界面にキトサン - カゼイン複合層を形成させたエマ
ルションでは, カゼインナトリウムのみで安定化され たエマルションと比較して次のような安定化効果が認 められた.すなわち，（1）油相の融解・再固化を伴う 加熱・冷却処理に打ける合一を抑制し，エマルション から油相成分が分離しにくくする効果，および（2）室 温での長期（7ヶ月）保存において油滴の合一・粗大結 晶化を抑制する効果が示された。 キトサンとカゼイン の複合化による物理的なバリア形成および油水界面を 介した物質移動の抑制に起因する結果と考えられるが, その詳細なメカニズムの解明には今後の検討が必要で ある. 固体/半固体油脂を含むエマルション製品にお いては，加工時における油滴の部分合一や，流通・保 存時の結晶生成が品質管理上の大きな問題となる。 今 回得られた知見および今後のさらなる検討により, 固 体 / 半固体油脂製品の安定性向上およびこれに付随す る機能性向上に資する可食性高分子の利用技術の開発 が期待される.

(受付 2021 年 8 月 25 日，受理 2021 年 10 月 20 日) 